\title{
Integrated Weed Management Effect on Weeds and Seed Cotton Yield
}

\author{
Dr. N. Malarkodi \\ Department of Agronomy, Agricultural College and research institute, Madurai. Tamil Nadu Agricultural University, Tamil \\ Nadu, India.
}

\begin{abstract}
Integrated weed management is a system approach where by whole land use planning is done in advance to minimise the very invasion of weeds in aggressive forms and give crop plants a strongly competitive advantage over the weeds. Further, importance is given to involve more than one method of weed control in tackling the weeds so those broad spectrums of weeds are kept under check for longer period. A pre emergence herbicide take care of weeds only for a limited period and do not give long term weed control in a long duration crop like cotton where the problem of late emerging weeds arises and escape killing. So to attain a season long weed control, integration of chemical, mechanical and cultural methods holds a great promise in crop production. Hence, integrated weed management in cotton play important role in increasing crop production. Field experiments were conducted during 2013 and 2014, at Agricultural College and Research Institute, Madurai (Tamil Nadu Agricultural University) to study the effect of integrated weed management in rainfed cotton. The weed management practices consisted of pendimethalin $\left(1.0 \mathrm{~kg} . \mathrm{ha}^{-1}\right)$ and (Calotropisgigantea leaf extract spray at three concentrations $(10 \%, 20 \%$, and $30 \%)$ in combination with power weeder operation twice and manual weeding twice. From the results of the experiments, it could be recommended that the integrated weed management practices like, application of $P E$ pendimethalin at $1.0 \mathrm{~kg}$ ha ${ }^{-1}+$ power weeding on 40 DAS $\left(T_{11}\right)$ recorded higher seed cotton yield and economic return.
\end{abstract}

Keywords - Economic return, Weed density, Weed Dry weight, Yield.

\section{INTRODUCTION}

In India, cotton is grown under diverse agro-climatic conditions. Cotton is the most important commercial crop contributing nearly $65 \%$ of total raw material needs of textile industry in our country. India ranks first in global scenario occupying about $33 \%$ of the world cotton area but with regard to production it ranks second, next to China. Cotton varieties are cultivated at wider spacing, which in turn invites multiple weed species infestation. Weed competition is severe during its initial growth stages. The increasing cost and unavailability of labour in time has forced to use herbicides for weed control in cotton. Hence, there is a need for selection of preemergence herbicides to control early emerging weeds during initial crop growth period. So to attain a season long weed control, integration of chemical, mechanical and cultural methods holds a great promise in crop production. Hence, integrated weed management in cotton play important role in increasing crop production.

Panwaret al. (1995) found that the requirement of one hoeing before or after spraying pendimethalin would assist through improved soil moisture conservation and removal of weed population in cotton. Braret al. (1995) stated that pre emergence application of pendimethalin @ $1.5 \mathrm{~kg} \mathrm{ha}^{-1}$ followed by one hoeing at $30 \mathrm{DAS}$ was effective for the control of annual broad leaved and grassy weeds like Trianthemaportulacastrum and Eleusineindica. The total weed density was reduced by 60-70 per cent with application of pendimethalin at $1.0 \mathrm{~kg}$ $\mathrm{ha}^{-1}+$ hand weeding on 30 DAS (Viveket al., 2002). Pendimethalin at $1.0 \mathrm{~kg} \mathrm{ha}^{-1}$ as pre-emergence herbicide followed by one hand weeding at 30 DAS reduced the weed density and nutrient uptake by weeds (Chanderet al., 1994). Pre emergence application of pendimethalin $1.0 \mathrm{~kg} \mathrm{ha}^{-1}+$ one hand weeding resulted in maximum weed control in cotton (AICCIP, 1999). Velayutham(1996) reported that pre-emergence application of pendimethalin at $0.75 \mathrm{~kg} \mathrm{ha}^{-1}$ followed by one hand weeding resulted in the enhanced kapas yield which was comparable with hand weeding twice. Highest seed cotton yield (2318 $\mathrm{kg} \mathrm{ha}^{-1}$ ) was recorded with preemergence application of pendimethalin at $1.50 \mathrm{~kg} \mathrm{ha}^{-1}$ followed by one hoeing and was 72 per cent higher than the unweeded control (Braret al., 1999). Rajavelet al.(2002) obtained higher seed cotton yield of $1217 \mathrm{~kg} \mathrm{ha}^{-1}$ under integrated method of herbicide with manual weeding which was comparable with manual weeding twice (1205 $\left.\mathrm{kg} \mathrm{ha}^{-1}\right)$. Ali et al. (2005) reported that maximum increase in seed cotton yield was obtained with pendimethalin $2.5 \mathrm{~kg} \mathrm{ha}^{-1}$ in combination with interculturing with hand weeding. The highest seed cotton yield was obtained from application of pendimethalin $1.5 \mathrm{~kg} \mathrm{ha}^{-1}$ followed by hoeing (Shaikhet al. 2006). The higher seed cotton yield 
and benefit: cost ratio were recorded with three hand weedings and three hoeings followed by pre and postemergence application of pendimethalin and glyphosate with two hand weedings and two hoeings (Deshpandeet al., 2006).So to attain a season long weed control, integration of chemical, mechanical and cultural methods holds a great promise in cotton production. Hence, integrated weed management in cotton play important role in increasing crop production.

\section{MATERIALS AND METHODS}

Field experiments wereconducted at Agricultural College and Research Institute, Madurai during 2013 and 2014. Field trials were laid out in randomized block design with fourteen treatments replicated thrice. The weed management practices evaluated in the present study consisted ofPE Calotropisgigantea at $30 \%+$ one hand weeding on 40 DAS ( $\left.\mathrm{T}_{1}\right)$, PE Calotropisgigantea at $30 \%+$ one power weeding (PW) on $40 \mathrm{DAS}\left(\mathrm{T}_{2}\right)$, PE Calotropisgigantea at $30 \%+$ EPOE of Calotropisgigantea at $30 \%\left(\mathrm{~T}_{3}\right)$, PE Calotropisgigantea at $20 \%+$ one hand weeding on $40 \mathrm{DAS}\left(\mathrm{T}_{4}\right), \quad \mathrm{PE}$ Calotropisgigantea at $20 \%+$ one power weeding (PW) on 40 DAS( $\left.\mathrm{T}_{5}\right)$, PE Calotropisgigantea at $20 \%+$ EPOE of Calotropisgigantea at $20 \% \quad\left(\begin{array}{lll}\mathrm{T}_{6} & \end{array}\right), \quad \mathrm{PE}$ Calotropisgigantea at $10 \%+$ one hand weeding on 40 $\operatorname{DAS}\left(\mathrm{T}_{7}\right), \quad$ PE Calotropisgigantea at $10 \%+$ one power weeding (PW) on $40 \operatorname{DAS}\left(\mathrm{T}_{8}\right), \quad \mathrm{PE}$ Calotropisgigantea at $10 \%+$ EPOE of Calotropisgigantea at $10 \%$ ( $\left.\mathrm{T}_{9}\right)$, PE Pendimethalin @ $1.0 \mathrm{~kg} \cdot \mathrm{ha}^{-1}+$ one hand weeding on $40 \operatorname{DAS}\left(\mathrm{T}_{10}\right), \mathrm{PE}$ Pendimethalin@1.0 kg ha ${ }^{-1}+$ one power weeding (PW) on 40 DAS( $\left.\mathrm{T}_{11}\right)$, Two hand weeding at 20and 40 DAS( $\mathrm{T}_{12}$ ), Two power weeding at 20and $40 \mathrm{DAS}\left(\mathrm{T}_{13}\right)$ were tested and compared with unweeded control( $\left.\mathrm{T}_{14}\right)$.Leaf extracts of 10, 20 and 30 per cent concentrations were sprayed on 3 DAS as pre emergence (PE) and 10 DAS as early post emergence (EPoE) by using hand sprayer. Weed management practices (hand and power weeding) were done on 40 DAS.

\section{RESULTS}

\subsection{Effect onweeds}

Weed flora of the experimental field consisted of fourteen weeds and among these weeds, CyanodondactylonandEchinochloacolonumwere the dominantgrass, Cyperusrotunduswas the only sedge,Trianthemaportulacastrum,

CorchorustrilocularisandCleome viscose were the predominantbroad leaved weeds. The results of the experiment revealed that the broad leaved weeds dominated over grasses and sedges in cotton during the initial growth stage. Among broad leaved weeds, Trianthemaportulacastrumwas the dominant weed flora during both the years. Dominance of broad leaved weeds in early stages was due to their faster growth and deep root system and thus promoted the absorption of soil moisture.

3.1.1. Effect ontotal weed density, total weed dry weight and weed control efficiency

3.1.1.1. Total weed density

Significant variation in total weed density was observed among the weed control methods. At 20 DAS, lesser and comparable level of total weed density was observed in the application of PE pendimethalin at $1.0 \mathrm{~kg} \mathrm{ha}^{-1}+\mathrm{HW}$ $\left(\mathrm{T}_{10}\right)$ with $9.17 \mathrm{~m}^{-2} ; 4.68 \mathrm{~m}^{-2}$ and application of $\mathrm{PE}$ pendimethalin at $1.0 \mathrm{~kg} \mathrm{ha}^{-1}+\mathrm{PW}\left(\mathrm{T}_{11}\right)$ with $9.18 \mathrm{~m}^{-2}$; $4.31 \mathrm{~m}^{-2}$ during 2012 and 2013, respectively. At 40 DAS, during 2012 and 2013, lesser density of total weed was observedwith two hand weeding $\left(\mathrm{T}_{12}\right)$, two power weeding $\left(\mathrm{T}_{13}\right)$, application of PE pendimethalin at $1.0 \mathrm{~kg}$ $\mathrm{ha}^{-1}+\mathrm{HW}\left(\mathrm{T}_{10}\right)$ and PE pendimethalin at $1.0 \mathrm{~kg} \mathrm{ha}^{-1}+\mathrm{PW}$ $\left(\mathrm{T}_{11}\right)$ which were comparable with each other(Table 1$)$. At 60 DAS, lesser total weed density was found in two hand weeding $\left(\mathrm{T}_{12}\right)$ with $17.71 \mathrm{~m}^{-2} ; 6.82 \mathrm{~m}^{-2}$, PE pendimethalin at $1.0 \mathrm{~kg} \mathrm{ha}^{-1}+\mathrm{HW}\left(\mathrm{T}_{10}\right)$ with $18.04 \mathrm{~m}^{-2} ; 7.16 \mathrm{~m}^{-2}, \mathrm{PE}$ pendimethalin at $1.0 \mathrm{~kg} \mathrm{ha}^{-1}+\mathrm{PW}\left(\mathrm{T}_{11}\right)$ with $19.10 \mathrm{~m}^{-2}$; $7.66 \mathrm{~m}^{-2}$ and two power weeding $\left(\mathrm{T}_{13}\right)$ with $21.35 \mathrm{~m}^{-2}$; $8.79 \mathrm{~m}^{-2}$ which were comparable with each other during 2012 and 2013, respectively. The cotton crop under unweeded check had higher total weed density at all the stages of observation in both the years.

\subsubsection{Total weed dry weight}

Weed management practices imposed to cotton significantly influenced the total dry weight of weed.At 20 DAS, during 2012 and 2013, application of PE pendimethalin at1.0 $\mathrm{kg} \mathrm{ha}^{-1}+\mathrm{HW}\left(\mathrm{T}_{10}\right)$ and $\mathrm{PE}$ pendimethalin at $1.0 \mathrm{~kg} \mathrm{ha}^{-1}+\mathrm{PW}\left(\mathrm{T}_{11}\right)$ were comparable and recorded with lesser dry weight of total weed(Table 2). At 40 DAS, during 2012 and 2013, lesser dry weight of total weed was observed with two hand weeding $\left(\mathrm{T}_{12}\right)$, two power weeding $\left(\mathrm{T}_{13}\right)$, PE pendimethalin at $1.0 \mathrm{~kg}$ $\mathrm{ha}^{-1}+\mathrm{HW}\left(\mathrm{T}_{10}\right)$ and $\mathrm{PE}$ pendimethalin at $1.0 \mathrm{~kg} \mathrm{ha}^{-1}+\mathrm{PW}$ $\left(\mathrm{T}_{11}\right)$ which were comparable with each other. At 60 DAS, during 2012 and 2013, the lowest dry weight of total weed was registered with two hand weeding $\left(\mathrm{T}_{12}\right)$, $\mathrm{PE}$ pendimethalin at $1.0 \mathrm{~kg} \mathrm{ha}{ }^{-1}+\mathrm{HW}\left(\mathrm{T}_{10}\right), \quad \mathrm{PE}$ pendimethalin at $1.0 \mathrm{~kg} \mathrm{ha}^{-1}+\mathrm{PW}\left(\mathrm{T}_{11}\right)$ and two power weeding $\left(\mathrm{T}_{13}\right)$ and were comparable. Unweeded check observed with higher density of total weed at all the stages of observation during both the years.

\subsubsection{Weed control efficiency (WCE)}

During 2012, application of PE pendimethalin at $1.0 \mathrm{~kg} \mathrm{ha}^{-1}$ $+\mathrm{HW}\left(\mathrm{T}_{10}\right)$ and $\quad$ PE pendimethalin at $1.0 \mathrm{~kg} \mathrm{ha}^{-1}+$ 
PW $\left(T_{11}\right)$ registered higher WCE of 74.73 and 74.33 per cent, respectively at 20 DAS(Table 3). During 2012, at 40 DAS, two hand weeding $\left(T_{12}\right)$, two power weeding $\left(T_{13}\right)$, $\mathrm{PE}$ pendimethalin at $1.0 \mathrm{~kg} \mathrm{ha}^{-1}+\mathrm{HW}\left(\mathrm{T}_{10}\right)$ and $\mathrm{PE}$ pendimethalin at $1.0 \mathrm{~kg} \mathrm{ha}^{-1}+\mathrm{PW}\left(\mathrm{T}_{11}\right)$ recorded highest WCE of 68.73, 68.40, 65.94 and 65.65 per cent. At 60 DAS, two hand weeding $\left(\mathrm{T}_{12}\right)$, PE pendimethalin at $1.0 \mathrm{~kg} \mathrm{ha}^{-1}+$ HW $\left(\mathrm{T}_{10}\right)$, PE pendimethalin at $1.0 \mathrm{~kg} \mathrm{ha}^{-1}+\mathrm{PW}\left(\mathrm{T}_{11}\right)$ and two power weeding $\left(\mathrm{T}_{13}\right)$ were recorded with higher WCE of $88.25,87.92,87.66$ and 87.32 per cent, respectively. During 2013, at 20 DAS, higher WCE of 89.37 and 89.35 per cent were recorded with the application of $\mathrm{PE}$ pendimethalin at $1.0 \mathrm{~kg} \mathrm{ha}^{-1}+\mathrm{PW}\left(\mathrm{T}_{11}\right)$ and $\mathrm{PE}$ pendimethalin at $1.0 \mathrm{~kg} \mathrm{ha}^{-1}+\mathrm{HW}\left(\mathrm{T}_{10}\right)$. At $40 \mathrm{DAS}$, two hand weeding $\left(\mathrm{T}_{12}\right)$, two power weeding $\left(\mathrm{T}_{13}\right), \mathrm{PE}$ pendimethalin at $1.0 \mathrm{~kg} \mathrm{ha}^{-1}+\mathrm{HW}\left(\mathrm{T}_{10}\right)$ and $\mathrm{PE}$ pendimethalin at $1.0 \mathrm{~kg} \mathrm{ha}^{-1}+\mathrm{PW}\left(\mathrm{T}_{11}\right)$ recorded highest WCE of 77.84, 77.67,74.73 and 74.44 per cent. At 60 DAS, two hand weeding $\left(\mathrm{T}_{12}\right)$, application of PE pendimethalin at $1.0 \mathrm{~kg} \mathrm{ha}^{-1}+\mathrm{HW}\left(\mathrm{T}_{10}\right)$, PE pendimethalin at $1.0 \mathrm{~kg} \mathrm{ha}^{-1}+$ PW $\left(\mathrm{T}_{11}\right)$ and two power weeding $\left(\mathrm{T}_{13}\right)$ were recorded with higher WCE.

\subsubsection{Nutrient removal by weeds}

\subsubsection{Nitrogen}

At 60 DAS, there was significant variation in $\mathrm{N}$ depletion by weeds among different weed management practices was found in both the crops(Table 4).In the first and second crop, at $60 \mathrm{DAS}$, two hand weeding $\left(\mathrm{T}_{12}\right), \mathrm{PE}$ pendimethalin at $1.0 \quad \mathrm{~kg} \quad \mathrm{ha}^{-1}+\mathrm{HW} \quad\left(\mathrm{T}_{10}\right), \mathrm{PE}$ pendimethalin at $1.0 \mathrm{~kg} \mathrm{ha}^{-1}+\mathrm{PW}\left(\mathrm{T}_{11}\right)$ and two power weeding $\left(T_{13}\right)$ were comparable and reduced the $\mathrm{N}$ removal by weeds markedly from 7.12 to $7.35 \mathrm{~kg} \mathrm{ha}^{-1}$ in 2012 and 6.94 to $7.46 \mathrm{~kg} \mathrm{ha}^{-1}$ in 2013 compared to other weed management practices.Unweeded controlrecorded with highest removal of $\mathrm{N}$ by weeds by 17.86 and 15.47 $\mathrm{kg} \mathrm{ha}^{-1}$ during 2012 and 2013.

\subsubsection{Phosphorus}

Weed control methods caused significant variation in $\mathrm{P}$ uptake by weeds in cotton.During 2012 and 2013, at 60 DAS, two hand weeding $\left(T_{12}\right)$, PE pendimethalin at $1.0 \mathrm{~kg}$ $\mathrm{ha}^{-1}+\mathrm{HW}\left(\mathrm{T}_{10}\right)$, PE pendimethalin at $1.0 \mathrm{~kg} \mathrm{ha}^{-1}+\mathrm{PW}$ $\left(T_{11}\right)$ and two power weeding $\left(T_{13}\right)$ were comparable and analyzed with reduced $\mathrm{P}$ removal by weeds considerably from 3.71 to $4.09 \mathrm{~kg} \mathrm{ha}^{-1}$ in 2012 and 2.58 to $2.89 \mathrm{~kg} \mathrm{ha}^{-1}$ in 2013 as compared to control. During 2012 and 2013, at 60 DAS, unweeded control resulted in removal by weeds with 7.34 and $6.12 \mathrm{~kg} \mathrm{ha}^{-1}$ in 2012 and 2013(Table 4).

\subsubsection{Potassium}

During 2012 and 2013, at 60 DAS, significant variations in $\mathrm{K}$ removal by weeds were observed among the weed management practices(Table 4).At 60 DAS, two hand weeding $\left(\mathrm{T}_{12}\right)$, PE pendimethalin at $1.0 \mathrm{~kg} \mathrm{ha}^{-1}+\mathrm{HW}$ $\left(\mathrm{T}_{10}\right)$, PE pendimethalin at $1.0 \mathrm{~kg} \mathrm{ha}^{-1}+\mathrm{PW}\left(\mathrm{T}_{11}\right)$ and two power weeding $\left(\mathrm{T}_{13}\right)$ were found comparable and from 10.74 to $11.14 \mathrm{~kg} \mathrm{ha}^{-1}$ in 2012 and from 7.96 to $8.32 \mathrm{~kg}$ $\mathrm{ha}^{-1}$ in 2013 with reduced $\mathrm{K}$ removal by weeds compared to other weed management practices.At 60 DAS, removal of potassiumby weeds was highest under unweeded control with 21.06 and $17.13 \mathrm{~kg} \mathrm{ha}^{-1}$ in 2012 and 2013 respectively.

\section{2. Effect on yield attributes and seed cotton yield}

3. 2. 1. Monopodial branches plant ${ }^{-1}$

Weed management practices did not significantly influence the number of monopodial branches plant ${ }^{-1}$ in both the years(Table 5 and 6 ).

\section{2. 2. Yield characters}

The data on number of sympodial branches plant ${ }^{-1}$, number of bolls plant ${ }^{-1}$ and boll weight were recorded and presented under yield characters. Significant variation among the treatments was noticed for all the yield attributes(Table 5 and 6).

\section{2. 3. Sympodial branches plant ${ }^{-1}$}

The treatments such astwo hand weeding $\left(\mathrm{T}_{12}\right)$, PE pendimethalin at $1.0 \mathrm{~kg} \mathrm{ha}^{-1}+\mathrm{HW}\left(\mathrm{T}_{10}\right), \mathrm{PE}$ pendimethalin at $1.0 \mathrm{~kg} \mathrm{ha}^{-1}+\mathrm{PW}\left(\mathrm{T}_{11}\right)$ and two power weeding $\left(\mathrm{T}_{13}\right)$ were comparable and recorded with sympodial branches plant ${ }^{-1}$ of 19.36,19.11,18.96 and 18.23 in 2012 and 21.53.21.47,21.33 and 20.45 in 2013 (Table 5 and 6).Unweeded control registered lesser number of sympodial branches plant ${ }^{-1} 8.41$ and 10.37 in 2012 and 2013.

\section{2. 4. Number of bolls plant ${ }^{-1}$}

The observation on boll number plant ${ }^{-1}$ showed that the weed management practices had significant effect on the boll production of cotton in the both the years of study.During 2012 and 2013, the treatments viz.,two hand weeding $\left(\mathrm{T}_{12}\right)$, PE pendimethalin at $1.0 \mathrm{~kg} \mathrm{ha}^{-1}+\mathrm{HW}$ $\left(\mathrm{T}_{10}\right), \mathrm{PE}$ pendimethalin at $1.0 \mathrm{~kg} \mathrm{ha}^{-1}+\mathrm{PW}\left(\mathrm{T}_{11}\right)$ and two power weeding $\left(T_{13}\right)$ were comparable and recorded with higher number of bolls plant ${ }^{-1}$ (Table 5 and 6). Unweeded control registered lesser number of bolls plant ${ }^{-1}$ of 11.60 and 12.90 in 2012 and 2013.

\section{2. 5. Boll weight}

In both the years of study, two hand weeding $\left(\mathrm{T}_{12}\right)$ showed higher boll weight of 3.72 and $3.91 \mathrm{~g}$ which were on par with $\mathrm{T}_{10}, \mathrm{~T}_{11}, \mathrm{~T}_{13}, \mathrm{~T}_{1}, \mathrm{~T}_{2}, \mathrm{~T}_{4}, \mathrm{~T}_{5}, \mathrm{~T}_{7}$ and $\mathrm{T}_{8}$ treatments produced bolls with more weight during 2012 and 2013 respectively(Table 5 and 6). Unweeded control registered 
the lowest boll weight of 2.87 and $2.96 \mathrm{~g} \mathrm{boll}^{-1}$ in both the years. But it was on par with $\mathrm{T}_{3}, \mathrm{~T}_{6}$ and $\mathrm{T}_{9}$ also.

\section{2. 6. Seed cotton yield}

In the present investigation, significant difference in seed cotton yield was observed among the various weed management practices with chemical, leaf extracts, manual mechanical methods and integrated weed management in both the years of study.During 2012, the maximum seed cotton yield of $2185 \mathrm{~kg} \mathrm{ha}^{-1}$ was registered with two hand weeding $\left(\mathrm{T}_{12}\right)$ and the yield under this treatment was comparable with PE pendimethalin at $1.0 \mathrm{~kg} \mathrm{ha}^{-1}+\mathrm{HW}$ $\left(\mathrm{T}_{10}\right)$, PE pendimethalinat $1.0 \mathrm{~kg} \mathrm{ha}^{-1}+\mathrm{PW}\left(\mathrm{T}_{11}\right)$ and two power weeding $\left(\mathrm{T}_{13}\right)$ with the yield of $2123,2087,2045$ $\mathrm{kg} \mathrm{ha}^{-1}$ (Table 5 and 6).During 2013, two hand weeding $\left(\mathrm{T}_{12}\right)$ was comparable with PE pendimethalin at $1.0 \mathrm{~kg} \mathrm{ha}^{-}$ ${ }^{1}+\mathrm{HW}\left(\mathrm{T}_{10}\right)$, PE pendimethalin at $1.0 \mathrm{~kg} \mathrm{ha}^{-1}+\mathrm{PW}\left(\mathrm{T}_{11}\right)$ and two power weeding $\left(\mathrm{T}_{13}\right)$ which registered higher seed cotton yield of 2293, 2232,2196 and $2174 \mathrm{~kg} \mathrm{ha}^{-1}$ respectively. Unweeded control recorded lesser seed cotton yield of 1356 and $1517 \mathrm{~kg} \mathrm{ha}^{-1}$ in both the years respectively.

\section{3. Economics}

The cost of cultivation was highest in hand weeded twice $\left(T_{12}\right)$ with Rs. 50,049 per hectare followed by $\mathrm{T}_{1}, \mathrm{~T}_{4}$ and $\mathrm{T}_{7}$ with Rs. 49,811 per hectare(Table 7 and 8).In both the crops, $\mathrm{PE}$ pendimethalin at $1.0 \mathrm{~kg} \mathrm{ha}^{-1}+\mathrm{HW}\left(\mathrm{T}_{10}\right)$, PE pendimethalin at $1.0 \mathrm{~kg} \mathrm{ha}^{-1}+\mathrm{PW}\left(\mathrm{T}_{11}\right)$ and hand weeding twice $\left(\mathrm{T}_{12}\right)$ recorded maximum net return. The unweeded control recorded the lowest net return of Rs. 13,156/- ha ${ }^{-1}$ and Rs. 14,268/- ha ${ }^{-1}$ during 2012 and 2013. Highest benefit cost ratio (B: C ratio) was obtained with the application of PE pendimethalin at 1.0 $\mathrm{kg} \mathrm{ha}^{-1}+\mathrm{PW}\left(\mathrm{T}_{11}\right)$ with 1.82 and 1.69 during 2012 and 2013. It was followed by PE pendimethalin at $1.0 \mathrm{~kg} \mathrm{ha}^{-1}+\mathrm{HW}$ $\left(\mathrm{T}_{10}\right)$ with 1.80 and 1.66 during the two years of study.

\section{DISCUSSION}

4. 1. Effect of weed control treatments on weed density, weed dry weight and weed control efficiency

Among the broad leaved weeds, Trianthemaportulacastrumwas the dominant weed flora during both the years of study. This might be due to the smothering effect of broad leaved weeds on monocots. The leaf area of the weed was more favourable for interception of brighter solar radiation. Nazaret al. (2008) reported that dominance of broad leaved weeds during the early stages of cotton was due to their fast growth and deep root system.

In the early stage of the crop growth (20 DAS), total weed density, total weed dry weight, were reduced greatly by the application of PE pendimethalin at $1.0 \mathrm{~kg} \mathrm{ha}^{-1}+\mathrm{HW}$ $\left(\mathrm{T}_{10}\right)$ and PE pendimethalin at $1.0 \mathrm{~kg} \mathrm{ha}^{-1}+\mathrm{PW}\left(\mathrm{T}_{11}\right)$.
Prabhu (2010) pointed out that broad spectrum action of pendimethalin recorded lesser density of grasses at 25 DAS due to the translocative nature of the herbicide. At 20 DAS, the sedge weeds were not satisfactorily controlled by pendimethalin 30 per cent EC formulation. It was supported by Nair et al. (1983) stating the failure of pendimethalin to control nutsedge. Pre emergence application of pendimethalin effectively reduced Trianthemaportulacastrum which was the predominant weed in the experimental site. This might be possibly due to the effective prevention of seed germination of broad leaved weeds.Nalini (2010) reported that pendimethalin effectively controlled annual weeds than perennial weeds. Das and Duary (1998) reported that the herbicidal effect of pendimethalin might be due to the inhibition of cell division and thus curtailed the density of weeds. The reduced weed dry weight could be due to the reduction in weed density at all the stages of crop growth. This might be attributed to rapid depletion of carbohydrate reserve of the weeds through rapid respiration as pointed out by Prakashet al. (1999).At 20 DAS, application of PE pendimethalin at $1.0 \mathrm{~kg} \mathrm{ha}^{-1}+\mathrm{HW}$ and PE pendimethalinat $1.0 \mathrm{~kg} \mathrm{ha}^{-1}+\mathrm{PW}$ recorded the highest WCE of 74.7; 89.35 and 74.33; 89.37 per cent in 2012 and 2013, respectively.

But at later stages of crop growth (40 DAS), total weed density, total weed dry weight, were reduced by manual weeding twice $\left(T_{12}\right)$ and power weeding twice $\left(T_{13}\right)$. The underground root portions like tubers and stolens were effectively removed by mechanical methods of weed control than the chemical application. This was due to the imposement of first manual weeding on 20 DAS which avoided the competition by weeds with crop for nutrient and moisture (Prabhu, 2010). Shobana (2002) reported that Cynodondactylon, was perennial in nature which was not much controlled by pendimethalin application. At this stage, manual weeding twice controlled the grass and sedge weed efficiently and favored the growth of cotton which influenced the crop and covered the field surface area much earlier than the weed.

At 60 DAS, both mechanical methods namely manual weeding twice $\left(T_{12}\right)$ and power weeding twice $\left(T_{13}\right)$ and integrated weed management viz, application of $\mathrm{PE}$ pendimethalin at $1.0 \mathrm{~kg} \mathrm{ha}^{-1}+\mathrm{HW}\left(\mathrm{T}_{10}\right)$ and $\mathrm{PE}$ pendimethalin at $1.0 \mathrm{~kg} \mathrm{ha}^{-1}+\mathrm{PW}\left(\mathrm{T}_{11}\right)$ effectively controlled all the weeds and reduced the dry weight of weedsultimately lead to better weed control efficiency in the above treatments. Shobana (2002) reported that the mechanical methods were better in weed control due to better removal of perennial weeds at 20 and 40 DAS. The early emerging weeds were controlled by first hand weeding and late emerging weeds were removed by second hand weeding with better removal of underground root portions. The integrated weed management practice 
registered the broad spectrum weed control as a result of longer persistence in the soil profile. Similar finding was reported by Balasubramanian (1992) who found that the weed control efficiency was comparatively higher with the application of pendimethalin at $1.0 \mathrm{~kg} \mathrm{ha}^{-1}$ as compared with 0.5 and $0.75 \mathrm{~kg} \mathrm{ha}^{-1}$.

The nutrient (NPK) removal by weeds was greatly reduced by two hand weeding $\left(\mathrm{T}_{12}\right)$, PE pendimethalin at $1.0 \mathrm{~kg} \mathrm{ha}^{-1}+\mathrm{HW}\left(\mathrm{T}_{10}\right)$, PE pendimethalinat $1.0 \mathrm{~kg} \mathrm{ha}^{-1}+$ PW $\left(T_{11}\right)$ and power weeding twice $\left(T_{13}\right)$. This might be due to fairly weed free condition at early stages of crop growth and the weed free environment created by the pre emergence herbicide with reduced weed DMP. The dry weight was another factor determining the nutrient removal by weeds. This finding is in line with the reports of Chanderet al. (1994) who described that application of pendimethalin at $1.25 \mathrm{~kg} \mathrm{ha}^{-1}$ followed by hand weeding reduced the nutrient removal by weeds which was comparable with hand weeding twice. Such positive effect was due to lower population and dry weight of weeds resulting from better control of the entire weed by two hand weeding.

\section{2. Effect on yield attributes and seed cotton yield}

Cotton being a wide spaced and slow growing crop is sensitive to weed competition at early stages of growth than at later stages. Due to heavy infestation of weeds under unweeded check reduction in seed cotton yield was recorded. During both the years, growth character number of monopodial branches plant ${ }^{-1}$ was not significantly influenced by the weed management practices. The yield attributing characters viz., number of sympodial branches plant ${ }^{-1}$, number of bolls plant ${ }^{-1}$ and boll weight ultimately decide the seed cotton yield. During both the years, the treatments had significant effect on yield attributes and seed cotton yield. The yield attributes andseed cotton yieldwere more with manual weeding twice $\left(\mathrm{T}_{12}\right)$, PE pendimethalin at $1.0 \mathrm{~kg} \mathrm{ha}^{-1}+\mathrm{HW}\left(\mathrm{T}_{10}\right)$, $\mathrm{PE}$ pendimethalin at $1.0 \mathrm{~kg} \mathrm{ha}^{-1}+\mathrm{PW}\left(\mathrm{T}_{11}\right)$ and power weeding twice $\left(T_{13}\right)$. This could be due to the enhanced plant height, dry matter production and nutrient uptake of the crop. This might also be due to the season long weed control which was favourable for better growth and enhanced leaf area contributing for the activated photosynthesis and translocation of more photosynthates to sink which increased the boll weight (Nalini, 2010).In the above treatments the yield increasing percentage over control was 61, 57, 54 and 51 per cent during 2012 and 51, 47, 45 and 43 per cent during 2013, respectively. Gnanavel and Babu (2008) also reported maximum seed cotton yield with pendimethalin combined with hand weeding as compared with control.
4. 3. Effect of weed control treatments on economics

Weed management practices showed positive impact on net return and benefit-cost ratio. By considering the cost of cultivation, pre emergence application of pendimethalin at1.0 $\mathrm{kg} \mathrm{ha}^{-1}+$ power weeding $\left(\mathrm{T}_{11}\right)$ resulted in higher net return of Rs.37,529/- during 2012 and Rs. 35,895/- during 2013 and benefit cost ratio of 1.82 and 1.69 during both the years, respectively. In the above treatment, the additional income obtained over unweeded control was Rs. 24,373/- and Rs. 21,627/during 2012 and 2013 respectively.

\section{CONCLUSION}

From the above study, it could be concluded, that the integrated weed management practices like, application of PE pendimethalin at $1.0 \mathrm{~kg} \mathrm{ha}^{-1}+$ power weeding on 40 DAS $\left(\mathrm{T}_{11}\right)$ could keep the weed density and dry weight reasonably at a lower level and recorded higher seed cotton yield and economic net return. The integrated weed management practices also performed equally effective as that of mechanical methods because of good control of early emerging weeds by the pre emergence herbicide application and better removal of late emerging weeds by mechanical methods of weed control.

\section{ACKNOWLEDGEMENT}

The author has been thankful to Tamil Nadu Agricultural University, Coimbatore, for providing the Research Assistant Scholarship during the period of study.

\section{REFERENCES}

[1] H. Ali,D. Muhammad and S.A. Abid, Weed control practices in cotton (Gossypiumhisrsutum L.) planted in beds and furrow. Pak. J. Weed Sci. Res., 11(1-2): 43-48,2005.

[2] K. Balasubramanian, Studies on chemical and tillage method of weed control in cotton and residual effect of herbicides on succeeding crops.Ph.D. Thesis, Tamil Nadu Agricultural University,, Coimbatore, India, p.110, 1992.

A. S. Brar,R.J.S. Thindand L.S.Brar,Integrated weed control in upland cotton (Gossypiumhirsutum L.). Indian J. Weed Sci., 27(3\&4): 138-143.1995.

[3] A.S. Brar, R.J.S. Thindand L.S. Brar,Integrated weed management in American cotton. J. Res. Punjab Agric. Univ.,36(3-4): 194-198.1999.

[4] S. Chander, S.K. Kahal and B.S.Panwar,Nutrient uptake by american cotton and weeds under different fertility levels and methods of weed control. Harayan J. Agron.,10(2): 237 - 239,1994.

[5] T.K.Das, and B.Duray,Pendimethalin, an excellent herbicide for weed control in crops. Intensive Agri.,36(5-6):18-20, 1998. 
[6] R. M. Deshpande,W.S. Pawar, P.S. Mankar, P.N. Bobdeand A.N. Chimote, Integrated weed management in rainfed cotton (Gossypiumhirsutum L.). Indian J. Agron., 51(1): 68-69, 2006.

[7] Gnanavel and S.Babu,Integrated weed management in irrigated hybrid cotton. Agric. Sci. Digest, 28(2): 93-96, 2008.

[8] P.K.R.Nair, J.P. Tiwariand N. Rahman,Weed control by herbicides in tomato.Indian J. Weed Sci., 15(1): 77-79, 1983.

[9] K. Nalini, Evaluation of pre-emergence herbicide in winter irrigated cotton and its residual effect on succeeding crops.Ph.D. Thesis, Tamil Nadu Agricultural University, Coimbatore, India, p.102, 2010.

[10]R. Nazar, S.Begum, A.Naz1, R. Qureshi,R. A.Memon,A. K. Chaudhryand Z.Akram,Weed flora of PirMehr Ali Shah Arid Agriculture University Rawalpindi. Pak. J. Weed Sci. Res., 14 (1-2): 55-72, 2008.

[11] R.S. Panwar, R.K. Malik,R.S. Banga and O.P. Kataria,Effect of time of pendimethalin application on weed control in cotton.Haryana J. Agron.,13(1): 78-80, 1995.

[12]M. Prabhu, Evaluation of integrated weed management practices in btcotton.M.Sc., Thesis, Tamil Nadu Agricultural University,Coimbatore, Tamil Nadu, India, p.112, 2010.
[13] Prakash,V., A.K. Pandey, P.Singh, S.Chandra,V.S. Chauhan and R.D. Singh,Integrated weed management in tomato under north-western Himalaya. Crop Res., 17(3): 345-350, 1999.

[14] M. Rajavel, N. Arunachalam,O.S. Kandasamy, S. Natarajanand K. Ramamoorthy, Allelopathic effect of plant materials on weed growth and yield of irrigated cotton var. MCU 5 (Gossypiumhirsutum L.). Madras Agric. J.,89(4-6): 363-365,2002.

[15] M.A. Shaikh, A. Saleemand N.A. Malik, Integrated weed management and its effect on the seed cotton yield in cotton crop. Pak. J. Weed Sci. Res.,12(1-2): 111-117, 2006.

[16] J. Shobana, Studies on plant leachates, herbicide and manual weeding as weed management practices in maize based intercropping system.M.Sc., Thesis, Tamil Nadu Agricultural University, Coimbatore, India, p.92, 2002.

[17] A.Velayutham, Studies on the bio-efficacy of herbicides and their application techniques in cotton based intercropped systems. Ph.D. Thesis.Tamil Nadu Agricultural University, Coimbatore, India, p.99, 1996.

[18] S. Vivek, S. TripathiandB.P. Dhyani, Integrated weed management in cotton in cotton-wheat system. Indian J. Weed Sci.,34(3\&4): 243-246, 2002.

Table.1: Effect of different weed management practices on total weed densityin cotton

\begin{tabular}{|c|c|c|c|c|c|c|}
\hline \multirow{3}{*}{ Treatments } & \multicolumn{6}{|c|}{ Total weed density(No. $\left.\mathrm{m}^{-2}\right)$} \\
\hline & \multicolumn{3}{|c|}{2012} & \multicolumn{3}{|c|}{2013} \\
\hline & $20 \mathrm{DAS}$ & 40 DAS & $60 \mathrm{DAS}$ & 20 DAS & 40 DAS & 60 DAS \\
\hline $\begin{array}{cl}T_{1}- & \text { PE Calotropis @ } 30 \% \\
+ & \text { HW on 40 DAS }\end{array}$ & $\begin{array}{l}33.75 \\
(5.81)\end{array}$ & $54.20(7.36)$ & $44.72(6.69)$ & $\begin{array}{l}24.89 \\
(4.99)\end{array}$ & $\begin{array}{l}37.96 \\
(6.16)\end{array}$ & $\begin{array}{l}27.24 \\
(5.22)\end{array}$ \\
\hline $\begin{array}{ll}\mathrm{T}_{2}- & \text { PE Calotropis @ } 30 \% \\
& + \text { PW on 40 DAS } \\
\end{array}$ & $\begin{array}{l}34.52 \\
(5.88) \\
\end{array}$ & $55.36(7.44)$ & $46.90(6.85)$ & $\begin{array}{l}25.49 \\
(5.05) \\
\end{array}$ & $\begin{array}{l}38.56 \\
(6.21) \\
\end{array}$ & $\begin{array}{l}29.39 \\
(5.42) \\
\end{array}$ \\
\hline $\begin{array}{c}\mathrm{T}_{3} \text { - PE Calotropis @ 30\% } \\
\text { + EPoECalotropis@ @ 30\% }\end{array}$ & $\begin{array}{l}32.02 \\
(5.66)\end{array}$ & $51.11(7.15)$ & $109.78(10.48)$ & $\begin{array}{l}23.66 \\
(4.86)\end{array}$ & $\begin{array}{l}35.82 \\
(5.99)\end{array}$ & $\begin{array}{l}82.34 \\
(9.07)\end{array}$ \\
\hline $\begin{array}{ll}\mathrm{T}_{4}- & \text { PE Calotropis @ } 20 \% \\
+ & \text { HW on 40 DAS } \\
\end{array}$ & $\begin{array}{l}46.79 \\
(6.84) \\
\end{array}$ & $72.23(8.50)$ & $54.44(7.38)$ & $\begin{array}{l}31.05 \\
(5.57) \\
\end{array}$ & $\begin{array}{l}50.57 \\
(7.11) \\
\end{array}$ & $\begin{array}{l}38.33 \\
(6.19) \\
\end{array}$ \\
\hline $\begin{array}{c}\mathrm{T}_{5}-\quad \text { PE Calotropis @ } 20 \% \\
+ \text { PW on 40 DAS }\end{array}$ & $\begin{array}{l}47.70 \\
(6.91)\end{array}$ & $72.87(8.54)$ & $56.92(7.54)$ & $\begin{array}{l}31.78 \\
(5.64)\end{array}$ & $\begin{array}{l}51.00 \\
(7.14)\end{array}$ & $\begin{array}{l}40.19 \\
(6.34)\end{array}$ \\
\hline $\begin{array}{c}\mathrm{T}_{6} \text { - PE Calotropis @ 20\% } \\
\text { + EPoECalotropis@ @ 20\% }\end{array}$ & $\begin{array}{l}44.49 \\
(6.67)\end{array}$ & $68.81(8.30)$ & $113.84(10.67)$ & $\begin{array}{l}29.26 \\
(5.41)\end{array}$ & $\begin{array}{l}46.85 \\
(6.84)\end{array}$ & $\begin{array}{l}85.97 \\
(9.27)\end{array}$ \\
\hline $\begin{array}{cl}\mathrm{T}_{7}- & \text { PE Calotropis @ } 10 \% \\
+ & \text { HW on 40 DAS }\end{array}$ & $\begin{array}{l}66.67 \\
(8.17)\end{array}$ & $93.89(9.69)$ & $67.17(8.20)$ & $\begin{array}{l}46.45 \\
(6.82)\end{array}$ & $\begin{array}{l}69.76 \\
(8.35)\end{array}$ & $\begin{array}{l}46.81 \\
(6.84)\end{array}$ \\
\hline $\begin{array}{ll}\mathrm{T}_{8}- & \text { PE Calotropis @ } 10 \% \\
& +\mathrm{PW} \text { on 40 DAS } \\
\end{array}$ & $\begin{array}{l}67.96 \\
(8.24) \\
\end{array}$ & $95.52(9.77)$ & $69.68(8.35)$ & $\begin{array}{l}47.24 \\
(6.87)\end{array}$ & $\begin{array}{l}70.95 \\
(8.42) \\
\end{array}$ & $\begin{array}{l}48.44 \\
(6.96)\end{array}$ \\
\hline $\begin{array}{c}\mathrm{T}_{9} \text { - PE Calotropis @ } 10 \% \\
\text { + EPoECalotropis@ } 10 \%\end{array}$ & $\begin{array}{l}62.85 \\
(7.93)\end{array}$ & $91.65(9.57)$ & $120.44(10.97)$ & $\begin{array}{l}43.54 \\
(6.60)\end{array}$ & $\begin{array}{l}65.06 \\
(8.07)\end{array}$ & $\begin{array}{l}90.20 \\
(9.50)\end{array}$ \\
\hline $\begin{array}{c}\mathrm{T}_{10}-\quad \text { Pendi. @ } 1.0 \mathrm{~kg} \mathrm{ha}^{-1} \\
+\mathrm{HW} \text { on } 40 \mathrm{DAS}\end{array}$ & $\begin{array}{c}9.17 \\
(3.03)\end{array}$ & $29.04(5.39)$ & $18.04(4.25)$ & $\begin{array}{l}4.68 \\
(2.16)\end{array}$ & $\begin{array}{l}13.76 \\
(3.61)\end{array}$ & $\begin{array}{l}7.16 \\
(2.68)\end{array}$ \\
\hline
\end{tabular}




\begin{tabular}{|cc|c|c|c|c|c|c|}
\hline $\mathrm{T}_{11}-$ & $\begin{array}{c}\text { Pendi. @ 1.0 kg ha } \\
\text { PW on 40 DAS }\end{array}$ & $\begin{array}{c}9.18 \\
(3.03)\end{array}$ & $29.73(5.45)$ & $19.10(4.37)$ & $\begin{array}{c}4.31 \\
(2.08)\end{array}$ & $\begin{array}{c}14.41 \\
(3.65)\end{array}$ & $\begin{array}{c}7.66 \\
(2.77)\end{array}$ \\
\hline $\mathrm{T}_{12}-$ & HW on 20 and 40 DAS & $\begin{array}{c}81.19 \\
(9.01)\end{array}$ & $23.36(4.83)$ & $17.71(4.21)$ & $\begin{array}{c}58.87 \\
(7.67)\end{array}$ & $\begin{array}{c}9.74 \\
(3.12)\end{array}$ & $\begin{array}{c}6.82 \\
(2.61)\end{array}$ \\
\hline \multirow{2}{*}{$\mathrm{T}_{13}-$} & PW on 20 and 40 DAS & $\begin{array}{c}80.49 \\
(8.97)\end{array}$ & $25.47(5.05)$ & $21.35(4.62)$ & $\begin{array}{c}59.15 \\
(7.69)\end{array}$ & $\begin{array}{c}11.02 \\
(3.32)\end{array}$ & $\begin{array}{c}8.79 \\
(2.96)\end{array}$ \\
\hline \multirow{2}{*}{$\mathrm{T}_{14}-\quad$ Unweeded control } & $\begin{array}{c}81.19 \\
(9.01)\end{array}$ & $\begin{array}{c}109.29 \\
(10.45)\end{array}$ & $134.17(11.58)$ & $\begin{array}{c}59.67 \\
(7.72)\end{array}$ & $\begin{array}{c}79.37 \\
(8.91)\end{array}$ & $\begin{array}{c}99.00 \\
(9.95)\end{array}$ \\
\hline \multicolumn{2}{|c|}{$\mathrm{S}$ Ed } & 0.275 & 0.345 & 0.360 & 0.220 & 0.270 & 0.295 \\
\hline \multicolumn{2}{|c|}{ CD (P=0.05) } & 0.55 & 0.69 & 0.72 & 0.44 & 0.54 & 0.59 \\
\hline
\end{tabular}

Figures in the parenthesis are transformed values

Table.2:.Effect of different weed management practices on total weed dry weight in cotton

\begin{tabular}{|c|c|c|c|c|c|c|}
\hline \multirow{3}{*}{ Treatments } & \multicolumn{6}{|c|}{ Total weed dry weight $\left(\mathrm{kg} \mathrm{ha}^{-1}\right)$} \\
\hline & \multicolumn{3}{|c|}{2012} & \multicolumn{3}{|l|}{2013} \\
\hline & 20 DAS & 40 DAS & 60 DAS & 20 DAS & 40 DAS & 60 DAS \\
\hline $\begin{array}{l}\mathrm{T}_{1}-\mathrm{PE} \text { Calotropis @ } 30 \%+\mathrm{HW} \\
\text { on 40 DAS }\end{array}$ & $\begin{array}{l}146.07 \\
(12.09)\end{array}$ & $\begin{array}{l}209.29 \\
(14.47)\end{array}$ & $\begin{array}{l}98.08 \\
(9.90)\end{array}$ & $\begin{array}{l}112.61 \\
(10.61)\end{array}$ & $\begin{array}{l}154.40 \\
(12.43)\end{array}$ & $\begin{array}{l}76.34 \\
(8.74)\end{array}$ \\
\hline $\begin{array}{l}\mathrm{T}_{2}-\quad \text { PE Calotropis @ } 30 \%+\mathrm{PW} \\
\text { on 40 DAS }\end{array}$ & $\begin{array}{l}145.99 \\
(12.08)\end{array}$ & $\begin{array}{l}209.71 \\
(14.48)\end{array}$ & $\begin{array}{l}99.41 \\
(9.97)\end{array}$ & $\begin{array}{l}112.91 \\
(10.63)\end{array}$ & $\begin{array}{l}154.87 \\
(12.44)\end{array}$ & $\begin{array}{l}77.16 \\
(8.78) \\
\end{array}$ \\
\hline $\begin{array}{l}\mathrm{T}_{3}- \\
\text { EPoECalotropis @ } @ 30 \%\end{array}$ & $\begin{array}{l}144.76 \\
(12.03)\end{array}$ & $\begin{array}{l}207.60 \\
(14.41)\end{array}$ & $\begin{array}{l}325.32 \\
(18.04)\end{array}$ & $\begin{array}{l}111.33 \\
(10.55)\end{array}$ & $\begin{array}{l}152.87 \\
(12.36)\end{array}$ & $\begin{array}{l}257.95 \\
(16.06)\end{array}$ \\
\hline $\begin{array}{l}\mathrm{T}_{4}-\quad \text { PE Calotropis @ } 20 \%+\mathrm{HW} \\
\text { on } 40 \mathrm{DAS}\end{array}$ & $\begin{array}{l}151.97 \\
(12.33)\end{array}$ & $\begin{array}{l}226.03 \\
(15.03)\end{array}$ & $\begin{array}{l}101.99 \\
(10.10)\end{array}$ & $\begin{array}{l}117.05 \\
(10.82)\end{array}$ & $\begin{array}{l}163.02 \\
(12.77) \\
\end{array}$ & $\begin{array}{l}79.99 \\
(8.94) \\
\end{array}$ \\
\hline $\begin{array}{l}\mathrm{T}_{5}-\quad \text { PE Calotropis @ } 20 \%+\mathrm{PW} \\
\text { on } 40 \text { DAS }\end{array}$ & $\begin{array}{l}152.65 \\
(12.36) \\
\end{array}$ & $\begin{array}{l}226.71 \\
(15.06) \\
\end{array}$ & $\begin{array}{l}104.20 \\
(10.21) \\
\end{array}$ & $\begin{array}{l}117.81 \\
(10.85) \\
\end{array}$ & $\begin{array}{l}164.36 \\
(12.82) \\
\end{array}$ & $\begin{array}{l}80.60 \\
(8.98) \\
\end{array}$ \\
\hline $\begin{array}{l}\mathrm{T}_{6}-\quad \text { PE Calotropis @ } 20 \%+ \\
\text { EPoECalotropis@20\% }\end{array}$ & $\begin{array}{l}151.14 \\
(12.29)\end{array}$ & $\begin{array}{l}221.59 \\
(14.89)\end{array}$ & $\begin{array}{l}328.86 \\
(18.13)\end{array}$ & $\begin{array}{l}115.41 \\
(10.74)\end{array}$ & $\begin{array}{l}160.23 \\
(12.66)\end{array}$ & $\begin{array}{l}260.90 \\
(16.15)\end{array}$ \\
\hline $\begin{array}{l}\mathrm{T}_{7}-\quad \text { PE Calotropis @ } 10 \%+\mathrm{HW} \\
\text { on } 40 \text { DAS }\end{array}$ & $\begin{array}{l}206.03 \\
(14.35)\end{array}$ & $\begin{array}{l}348.29 \\
(18.66)\end{array}$ & $\begin{array}{l}110.55 \\
(10.51)\end{array}$ & $\begin{array}{l}170.10 \\
(13.04)\end{array}$ & $\begin{array}{l}258.11 \\
(16.07)\end{array}$ & $\begin{array}{l}83.26 \\
(9.12)\end{array}$ \\
\hline $\begin{array}{l}\mathrm{T}_{8}-\quad \text { PE Calotropis @ } 10 \%+\mathrm{PW} \\
\text { on 40 DAS }\end{array}$ & $\begin{array}{l}209.73 \\
(14.48) \\
\end{array}$ & $\begin{array}{l}355.56 \\
(18.86) \\
\end{array}$ & $\begin{array}{l}112.24 \\
(10.59) \\
\end{array}$ & $\begin{array}{l}171.07 \\
(13.08) \\
\end{array}$ & $\begin{array}{l}268.40 \\
(16.38) \\
\end{array}$ & $\begin{array}{l}84.52 \\
(9.19) \\
\end{array}$ \\
\hline $\begin{array}{l}\mathrm{T}_{9}-\quad \text { PE Calotropis @ } 10 \%+ \\
\text { EPoECalotropis@10\% }\end{array}$ & $\begin{array}{l}203.78 \\
(14.28)\end{array}$ & $\begin{array}{l}345.13 \\
(18.58)\end{array}$ & $\begin{array}{l}332.52 \\
(18.24)\end{array}$ & $\begin{array}{l}165.88 \\
(12.88)\end{array}$ & $\begin{array}{l}253.18 \\
(15.91)\end{array}$ & $\begin{array}{l}266.79 \\
(16.33)\end{array}$ \\
\hline $\begin{array}{l}\mathrm{T}_{10}-\quad \text { Pendi. @ } 1.0 \mathrm{~kg} \mathrm{ha}^{-1}+\mathrm{HW} \\
\text { on 40 DAS }\end{array}$ & $\begin{array}{l}63.84 \\
(7.99)\end{array}$ & $\begin{array}{l}127.31 \\
(11.28)\end{array}$ & $\begin{array}{l}43.82 \\
(6.62)\end{array}$ & $\begin{array}{l}22.33 \\
(4.73)\end{array}$ & $\begin{array}{l}71.46 \\
(8.45)\end{array}$ & $\begin{array}{l}19.74 \\
(4.44)\end{array}$ \\
\hline $\begin{array}{l}\mathrm{T}_{11}-\text { Pendi. @ } 1.0 \mathrm{~kg} \mathrm{ha}^{-1}+\mathrm{PW} \\
\text { on 40 DAS }\end{array}$ & $\begin{array}{l}64.84 \\
(8.05)\end{array}$ & $\begin{array}{l}128.42 \\
(11.33)\end{array}$ & $\begin{array}{l}44.76 \\
(6.69)\end{array}$ & $\begin{array}{l}22.30 \\
(4.72)\end{array}$ & $\begin{array}{l}72.27 \\
(8.50)\end{array}$ & $\begin{array}{l}20.34 \\
(4.51)\end{array}$ \\
\hline $\mathrm{T}_{12}-\quad \mathrm{HW}$ on 20 and 40 DAS & $\begin{array}{l}251.87 \\
(15.87)\end{array}$ & $\begin{array}{l}116.89 \\
(10.81)\end{array}$ & $\begin{array}{l}42.63 \\
(6.53) \\
\end{array}$ & $\begin{array}{l}207.78 \\
(14.41) \\
\end{array}$ & $\begin{array}{l}62.66 \\
(7.92) \\
\end{array}$ & $\begin{array}{l}18.95 \\
(4.35)\end{array}$ \\
\hline $\mathrm{T}_{13}-\quad \mathrm{PW}$ on 20 and $40 \mathrm{DAS}$ & $\begin{array}{l}252.05 \\
(15.88)\end{array}$ & $\begin{array}{l}118.14 \\
(10.87)\end{array}$ & $\begin{array}{l}46.00 \\
(6.78)\end{array}$ & $\begin{array}{l}208.24 \\
(14.43)\end{array}$ & $\begin{array}{l}63.15 \\
(7.95)\end{array}$ & $\begin{array}{l}21.22 \\
(4.61)\end{array}$ \\
\hline $\mathrm{T}_{14}-\quad$ Unweeded control & $\begin{array}{l}252.61 \\
(15.89)\end{array}$ & $\begin{array}{l}373.82 \\
(19.33)\end{array}$ & $\begin{array}{l}377.80 \\
(19.45)\end{array}$ & $\begin{array}{l}209.70 \\
(14.48)\end{array}$ & $\begin{array}{l}282.79 \\
(16.82)\end{array}$ & $\begin{array}{l}377.80 \\
(19.45)\end{array}$ \\
\hline S. Ed & 0.54 & 0.68 & 0.59 & 0.43 & 0.56 & 0.48 \\
\hline $\mathrm{CD}(\mathrm{P}=0.05)$ & 1.07 & 1.36 & 1.17 & 0.86 & 1.11 & 0.96 \\
\hline
\end{tabular}

Figures in the parenthesis are transformed values

Table.3: Effect of different weed management practices on the weed control efficiency (WCE) in cotton

\begin{tabular}{|c|c|c|c|c|c|c|c|}
\hline & \multirow{3}{*}{ Treatments } & \multicolumn{6}{|c|}{ Weed control efficiency $(\%)$} \\
\hline & & \multicolumn{3}{|c|}{2012} & \multicolumn{3}{|c|}{2013} \\
\hline & & $20 \mathrm{DAS}$ & 40 DAS & $60 \mathrm{DAS}$ & $\begin{array}{c}20 \\
\text { DAS }\end{array}$ & $40 \mathrm{DAS}$ & $60 \mathrm{DAS}$ \\
\hline $\mathrm{T}_{1}-$ & PE Calotropis@30\%+ HW on 40 DAS & 42.17 & 44.01 & 72.97 & 46.30 & 45.40 & 73.20 \\
\hline $\mathrm{T}_{2}-$ & PE Calotropis@30\%+PW on 40 DAS & 42.21 & 43.90 & 72.60 & 46.16 & 45.24 & 72.91 \\
\hline $\mathrm{T}_{3}-$ & PE Calotropis @ 30\%+EPoECalotropis & 42.69 & 44.46 & 10.34 & 46.91 & 45.94 & 9.44 \\
\hline
\end{tabular}




\begin{tabular}{|c|c|c|c|c|c|c|c|}
\hline \multicolumn{8}{|c|}{$@ 30 \%$} \\
\hline $\mathrm{T}_{4}-$ & PE Calotropis@20\%+HW on 40 DAS & 39.84 & 39.53 & 71.89 & 44.18 & 42.35 & 71.92 \\
\hline $\mathrm{T}_{5}-$ & PE Calotropis@20\%+PW on 40DAS & 39.57 & 39.35 & 71.28 & 43.82 & 41.88 & 71.70 \\
\hline $\mathrm{T}_{6}-$ & $\begin{array}{c}\text { PE Calotropis @ 20\% + EPoECalotropis } \\
@ 20 \%\end{array}$ & 40.17 & 40.72 & 9.36 & 44.97 & 43.34 & 8.41 \\
\hline $\mathrm{T}_{7}-$ & PE Calotropis@10\%+ HW on 40 DAS & 18.44 & 6.83 & 69.53 & 18.88 & 8.73 & 70.77 \\
\hline $\mathrm{T}_{8}-$ & PE Calotropis@10\%+PW on 40DAS & 16.97 & 4.88 & 69.07 & 18.42 & 5.09 & 70.33 \\
\hline $\mathrm{T}_{9}-$ & $\begin{array}{r}\text { PE Calotropis @ } 10 \%+\text { EPoECalotropis } \\
@ 10 \%\end{array}$ & 19.33 & 7.68 & 8.35 & 20.90 & 10.47 & 6.34 \\
\hline $\mathrm{T}_{10}-$ & Pendi.@1.0 kg ha- + HW on 40 DAS & 74.73 & 65.94 & 87.92 & 89.35 & 74.73 & 93.07 \\
\hline $\mathrm{T}_{11}-$ & Pendi. @ $1.0 \mathrm{~kg} \mathrm{ha}^{-1}+$ PW on $40 \mathrm{DAS}$ & 74.33 & 65.65 & 87.66 & 89.37 & 74.44 & 92.86 \\
\hline & $\mathrm{T}_{12}-\quad \mathrm{HW}$ on 20 and $40 \mathrm{DAS}$ & 0.29 & 68.73 & 88.25 & 0.91 & 77.84 & 93.35 \\
\hline & $\mathrm{T}_{13}-\quad \mathrm{PW}$ on 20 and 40 DAS & 0.22 & 68.40 & 87.32 & 0.70 & 77.67 & 92.55 \\
\hline & $\mathrm{T}_{14}-\quad$ Unweeded control & - & - & - & - & - & - \\
\hline
\end{tabular}

Table.4: Nutrient removal by weed at 60 DAS as influenced by weed management practices in cotton

\begin{tabular}{|c|c|c|c|c|c|c|}
\hline \multirow{3}{*}{ Treatments } & \multicolumn{6}{|c|}{$\mathrm{N}, \mathrm{P}, \mathrm{K}$ removal by weeds at 60 DAS $\left(\mathrm{kg} \mathrm{ha}^{-1}\right)$} \\
\hline & \multicolumn{3}{|c|}{2012} & \multicolumn{3}{|c|}{2013} \\
\hline & $\mathbf{N}$ & $\mathbf{P}$ & $\mathbf{K}$ & $\mathbf{N}$ & $\mathbf{P}$ & $\mathbf{K}$ \\
\hline PE Calotropis @ $30 \%+\mathrm{HW}$ on $40 \mathrm{DAS}$ & 10.75 & 5.17 & 12.63 & 9.87 & 3.71 & 10.73 \\
\hline PE Calotropis@ @ 30\%+ PW on 40 DAS & 10.87 & 5.32 & 12.71 & 9.95 & 3.78 & 10.99 \\
\hline PE Calotropis@30\%+EPoECalotropis @30\% & 16.81 & 6.89 & 19.69 & 14.59 & 5.75 & 16.09 \\
\hline PE Calotropis@20\%+HW on 40 DAS & 12.34 & 6.83 & 15.13 & 11.59 & 4.66 & 12.32 \\
\hline PE Calotropis@20\%+PW on 40 DAS & 12.82 & 6.91 & 15.34 & 11.69 & 4.75 & 12.56 \\
\hline PE Calotropis@20\%+EPoECalotropis@20\% & 16.99 & 6.96 & 19.78 & 14.72 & 5.86 & 16.25 \\
\hline PE Calotropis @ $10 \%+\mathrm{HW}$ on $40 \mathrm{DAS}$ & 13.15 & 6.13 & 15.45 & 12.11 & 4.76 & 12.75 \\
\hline PE Calotropis@ @ 10\%+ PW on 40 DAS & 13.27 & 6.22 & 15.59 & 12.38 & 4.84 & 12.87 \\
\hline PE Calotropis@10\%+EPoECalotropis@10\% & 17.34 & 7.13 & 19.83 & 15.01 & 5.91 & 16.54 \\
\hline Pendi. @ $1.0 \mathrm{~kg} \mathrm{ha}^{-1}+\mathrm{HW}$ on $40 \mathrm{DAS}$ & 7.22 & 3.88 & 10.89 & 7.15 & 2.71 & 8.09 \\
\hline Pendi. @ $1.0 \mathrm{~kg} \mathrm{ha}^{-1}+\mathrm{PW}$ on $40 \mathrm{DAS}$ & 7.29 & 3.96 & 10.96 & 7.32 & 2.80 & 8.15 \\
\hline HW on 20 and 40 DAS & 7.12 & 3.71 & 10.74 & 6.94 & 2.58 & 7.96 \\
\hline PW on 20 and 40 DAS & 7.35 & 4.09 & 11.14 & 7.46 & 2.89 & 8.32 \\
\hline Unweeded control & 17.86 & 7.34 & 21.06 & 15.47 & 6.12 & 17.13 \\
\hline S. Ed & 0.56 & 0.25 & 0.72 & 0.50 & 0.20 & 0.57 \\
\hline $\mathrm{CD}(\mathrm{P}=0.05)$ & 1.12 & 0.49 & 1.43 & 1.01 & 0.39 & 1.13 \\
\hline
\end{tabular}

Table.5: Effect of weed management practices on monopodial branches, yield attributes and yield of cotton in 2012

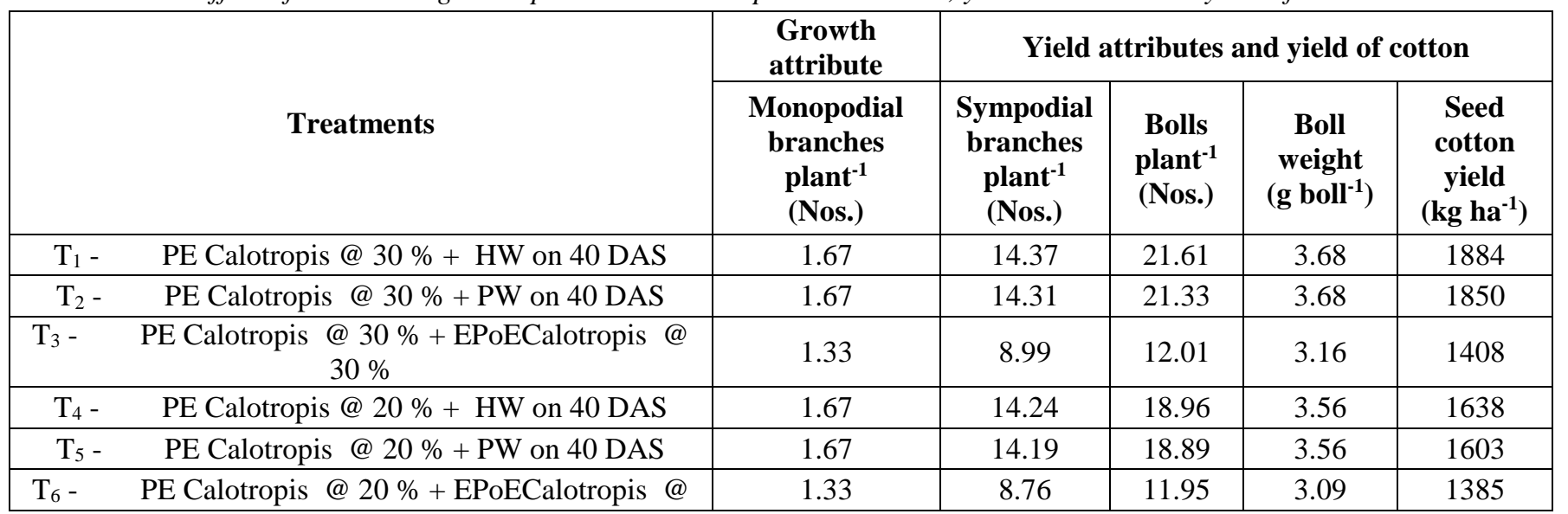




\begin{tabular}{|c|c|c|c|c|c|}
\hline $20 \%$ & & & & & \\
\hline PE Calotropis@10\%+ HW on 40 DAS & 1.67 & 13.34 & 18.62 & 3.47 & 1589 \\
\hline PE Calotropis@10\%+PW on 40 DAS & 1.67 & 13.25 & 18.56 & 3.47 & 1572 \\
\hline $\begin{array}{c}\mathrm{T}_{9} \text { - PE Calotropis @ 10\%+EPoECalotropis@ } \\
10 \%\end{array}$ & 1.33 & 8.65 & 11.78 & 2.96 & 1374 \\
\hline $\mathrm{T}_{10}-\quad$ Pendi. @ 1.0 $\mathrm{kg} \mathrm{ha}^{-1}+\mathrm{HW}$ on $40 \mathrm{DAS}$ & 1.67 & 19.11 & 23.42 & 3.71 & 2123 \\
\hline Pendi. @ $1.0 \mathrm{~kg} \mathrm{ha}^{-1}+$ PW on 40 DAS & 1.67 & 18.96 & 23.18 & 3.71 & 2087 \\
\hline $\mathrm{T}_{12}-\quad$ HW on 20 and 40 DAS & 1.67 & 19.36 & 24.50 & 3.72 & 2185 \\
\hline $\mathrm{T}_{13}-\quad \mathrm{PW}$ on 20 and $40 \mathrm{DAS}$ & 1.67 & 18.23 & 22.92 & 3.69 & 2045 \\
\hline $\mathrm{T}_{14-} \quad$ Unweeded control & 1.00 & 8.41 & 11.60 & 2.87 & 1356 \\
\hline S. Ed & 0.40 & 0.63 & 0.82 & 0.15 & 80 \\
\hline $\mathrm{CD}(\mathrm{P}=0.05)$ & NS & 1.25 & 1.63 & 0.30 & 159 \\
\hline
\end{tabular}

Table.6: Effect of weed management practices on monopodial branches, yield attributes and yield of cotton in 2013

\begin{tabular}{|c|c|c|c|c|c|}
\hline \multirow[b]{2}{*}{ Treatments } & \multirow{2}{*}{$\begin{array}{c}\begin{array}{c}\text { Growth } \\
\text { attribute }\end{array} \\
\text { Monopodial } \\
\text { branches } \\
\text { plant }^{-1} \\
\text { (Nos.) }\end{array}$} & \multicolumn{4}{|c|}{ Yield attributes and yield of cotton } \\
\hline & & $\begin{array}{c}\text { Sympodial } \\
\text { branches } \\
\text { plant }^{-1} \\
\text { (Nos.) }\end{array}$ & $\begin{array}{l}\text { Bolls } \\
\text { plant }^{-1} \\
\text { (Nos.) }^{\text {Not }}\end{array}$ & $\begin{array}{c}\text { Boll } \\
\text { weight } \\
\text { (g boll- } \\
1)\end{array}$ & $\begin{array}{c}\text { Seed } \\
\text { cotton } \\
\text { yield } \\
\left(\mathrm{kg} \mathrm{ha}^{-1}\right)\end{array}$ \\
\hline PE Calotropis @ 30\% + HW on 40 DAS & 1.67 & 18.96 & 20.12 & 3.70 & 2010 \\
\hline PE Calotropis@ @ $30 \%+$ PW on 40 DAS & 1.67 & 18.91 & 20.01 & 3.69 & 1998 \\
\hline PE Calotropis@30\%+EPoECalotropis @ 30\% & 1.33 & 10.57 & 14.21 & 3.00 & 1582 \\
\hline PE Calotropis @ 20\%+HW on 40 DAS & 1.67 & 18.75 & 17.43 & 3.67 & 1823 \\
\hline PE Calotropis@ $@ 20 \%+$ PW on 40 DAS & 1.67 & 18.68 & 17.13 & 3.67 & 1811 \\
\hline PE Calotropis@20\%+EPoECalotropis@20\% & 1.33 & 10.49 & 13.55 & 3.00 & 1560 \\
\hline PE Calotropis @ $10 \%+$ HW on 40 DAS & 1.67 & 17.86 & 16.75 & 3.65 & 1782 \\
\hline PE Calotropis@10\%+PW on 40 DAS & 1.67 & 17.79 & 19.64 & 3.63 & 1759 \\
\hline PE Calotropis@ @10\%+EPoECalotropis@ @10\% & 1.33 & 10.41 & 12.99 & 2.98 & 1541 \\
\hline Pendi. @ $1.0 \mathrm{~kg} \mathrm{ha}^{-1}+\mathrm{HW}$ on 40 DAS & 1.67 & 21.47 & 26.18 & 3.86 & 2232 \\
\hline Pendi. @ $1.0 \mathrm{~kg} \mathrm{ha}^{-1}+\mathrm{PW}$ on $40 \mathrm{DAS}$ & 1.67 & 21.33 & 25.82 & 3.81 & 2196 \\
\hline HW on 20 and 40 DAS & 2.00 & 21.53 & 26.30 & 3.91 & 2293 \\
\hline PW on 20 and 40 DAS & 2.00 & 20.45 & 24.76 & 3.75 & 2174 \\
\hline Unweeded control & 1.00 & 10.37 & 12.90 & 2.96 & 1517 \\
\hline S. Ed & 0.39 & 0.62 & 0.88 & 0.16 & 86 \\
\hline CD $(\mathbf{P}=0.05)$ & NS & 1.24 & 1.77 & 0.31 & 172 \\
\hline
\end{tabular}

Table.7: Economics of different weed management practices in cotton during 2012

\begin{tabular}{|l|c|c|c|c|}
\hline \multicolumn{1}{|c|}{ Treatments } & \multicolumn{3}{c|}{$\mathbf{2 0 1 2}$} \\
\cline { 2 - 5 } & $\begin{array}{c}\text { Total } \\
\text { (ost of cultivation } \\
\left(\mathbf{R s ~ h a}^{-1}\right)\end{array}$ & $\begin{array}{c}\text { Gross } \\
\text { income } \\
\left(\mathbf{R s ~ h a}^{-1}\right)\end{array}$ & $\begin{array}{c}\text { Net income } \\
\left(\text { Rs ha-1 }^{-1}\right)\end{array}$ & B:C ratio \\
\hline PE Calotropis @ 30\% + HW on 40 DAS & 49811 & 75360 & 24549 & 1.48 \\
\hline PE Calotropis @ 30\% + PW on 40 DAS & 48466 & 74000 & 24534 & 1.50 \\
\hline PE Calotropis @ 30\% +EPoECalotropis @ 30\% & 46388 & 56320 & 8932 & 1.19 \\
\hline PE Calotropis @ 20\% + HW on 40 DAS & 49811 & 65520 & 14709 & 1.29 \\
\hline PE Calotropis @ 20\% + PW on 40 DAS & 48466 & 64120 & 14654 & 1.30 \\
\hline PE Calotropis @ 20\% +EPoECalotropis @ 20\% & 46388 & 55400 & 8012 & 1.17 \\
\hline PE Calotropis @ 10\% + HW on 40 DAS & 49811 & 63560 & 12749 & 1.25 \\
\hline PE Calotropis @ 10\% + PW on 40 DAS & 48466 & 62880 & 13414 & 1.27 \\
\hline PE Calotropis @ 10\% +EPoECalotropis @ 10\% & 46388 & 54960 & 7572 & 1.16 \\
\hline
\end{tabular}




\begin{tabular}{|l|c|c|c|c|}
\hline Pendi. @ 1.0 kg ha-1 + HW on 40 DAS & 47296 & 84920 & 37624 & 1.80 \\
\hline Pendi. @ $1.0 \mathrm{~kg} \mathrm{ha}^{-1}+$ PW on 40 DAS & 45951 & 83480 & 37529 & 1.82 \\
\hline HW on 20 and 40 DAS & 50049 & 87400 & 37351 & 1.75 \\
\hline PW on 20 and 40 DAS & 46544 & 81800 & 35256 & 1.76 \\
\hline Unweeded control & 41084 & 54240 & 13156 & 1.32 \\
\hline
\end{tabular}

Table.8: Economics of different weed management practices in cotton during 2013

\begin{tabular}{|c|c|c|c|c|}
\hline \multirow[b]{2}{*}{ Treatments } & \multicolumn{4}{|c|}{2013} \\
\hline & $\begin{array}{c}\text { Total } \\
\text { cost of cultivation } \\
\left(\mathrm{Rs} \mathrm{h}^{-1}\right)\end{array}$ & $\begin{array}{c}\text { Gross } \\
\text { income } \\
\left(\text { Rs ha }^{-1}\right)\end{array}$ & $\begin{array}{l}\text { Net income } \\
\left(\text { Rs ha }^{-1}\right)\end{array}$ & B:C ratio \\
\hline PE Calotropis @ 30\%+ HW on 40 DAS & 56235 & 80400 & 23065 & 1.40 \\
\hline PE Calotropis@30\%+PW on 40 DAS & 54530 & 79920 & 24290 & 1.44 \\
\hline PE Calotropis@ @ 30\%+EPoECalotropis @ 30\% & 52308 & 63280 & 9872 & 1.18 \\
\hline PE Calotropis @ 20\% + HW on 40 DAS & 56235 & 72920 & 15585 & 1.27 \\
\hline PE Calotropis@ @ 20\%+ PW on 40 DAS & 54530 & 72440 & 16810 & 1.30 \\
\hline PE Calotropis@ $20 \%+$ +EPoECalotropis @ 20\% & 52308 & 62400 & 8992 & 1.17 \\
\hline PE Calotropis @ $10 \%+$ HW on 40 DAS & 56235 & 71280 & 13945 & 1.24 \\
\hline PE Calotropis@10\%+PW on 40 DAS & 54530 & 70360 & 14730 & 1.26 \\
\hline PE Calotropis@ @ $10 \%+E P o E C a l o t r o p i s @ 10 \%$ & 52308 & 61640 & 8232 & 1.15 \\
\hline Pendi. @ $1.0 \mathrm{~kg} \mathrm{ha}^{-1}+\mathrm{HW}$ on 40 DAS & 53650 & 89280 & 35630 & 1.66 \\
\hline Pendi. @ $1.0 \mathrm{~kg} \mathrm{ha}^{-1}+$ PW on 40 DAS & 51945 & 87840 & 35895 & 1.69 \\
\hline HW on 20 and 40 DAS & 56697 & 91720 & 35023 & 1.62 \\
\hline PW on 20 and 40 DAS & 52352 & 86960 & 34608 & 1.66 \\
\hline Unweeded control & 46412 & 60680 & 14268 & 1.31 \\
\hline
\end{tabular}

